\title{
Huge Lipoma in the Floor of the Mouth: A Case Report
}

\author{
HS Mubarak Hossain ${ }^{1}$, Ashfaq Ahmad, ${ }^{2}$ Mamoon Ibn Amin, ${ }^{3}$ Ziaul Answar Chowdhury ${ }^{4}$
}

\begin{abstract}
Lipomas are adipose mesenchymal neoplasms. The oral cavity is not commonly affected. representing about $0.5 \%$ to $5 \%$ of all benign oral tumors. The clinical presentation is typically as an asymptomatic yellowish mass. The overlying epithelium is intact and superficial blood vessels are usually evident over the tumour. Although benign in nature their progressive growth may cause interference with speech and mastication due to tumour's dimension. The present report shows the case of a 52-year old male who presented with a large intraoral lipoma with extension to the right submandibular region.
\end{abstract}

Key Words: Huge lipoma, Floor of the mouth

\section{Introduction}

Lipoma, a common soft tissue tumor is a slow-growing benign mesenchymal neoplasm composed of mature adipocytes surrounded by a thin capsule. ${ }^{1}$ Around $50 \%$ of the lesions are found in the cheeks and the remaining under the tongue, floor of mouth, palate, gingiva, and lips. ${ }^{2}$ They have no gender predilection but some studies have shown male predominance. ${ }^{3,4,5}$ They usually occur in the 4th-5th decade of life. In a review of more than 1000 benign tumors of adiposetissue, over $80 \%$ were lipoma; nearly

1. Junior Consultant (ENT), Upazila Health Complex, Boalkhali, Chittagong.

2. Senior Consultant (ENT), 250 Bed General Hospital, Chittagong.

3. Senior Consultant (ENT), 250 Bed General Hospital, Chittagong.

4. Junior Consultant (ENT), 250 Bed General Hospital, Chittagong.

Adress for correspondence: Dr.H. S. Mubarak Hossain, Flat 4D, H-22, R-01, Nasirabad Housing Society, Chittagong.cell: +88 01818832310, E-mail: mubadr@yahoo.com all the others were angiolipomas, intramuscular lipomas, or lipoblastomas ${ }^{6 .}$ Most of lipomas develop in the subcutaneous tissues but deeper tissues may be involved as well the oral cavity is not commonly affected $^{7}$. Oral lipomas can occur in various anatomic sites including the major salivary glands, buccal mucosa, lip, tongue, palate, vestibule and floor of mouth. ${ }^{8,9}$ The present report shows the case of a 52-year old male who presented with a large intraoral lipoma with extension to the submandibular region.

\section{Case Report}

A 52 years old otherwise healthy man was presented with a huge swelling in the right side of the floor of the mouth. The swelling increased gradually and extended to the right submandibular region for last one year. The swelling was painless and slow growing. It gradually impaired the movement of the tongue speech and deglutition. It crossed the midline and extended from whole anterior part of floor of mouth to right lower last molar tooth. In the neck the swelling occupied right submental and submandibular region. 


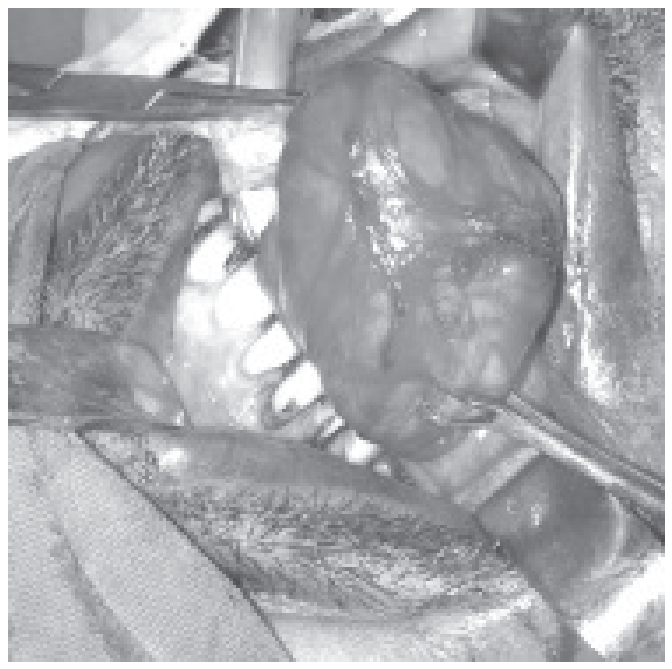

Fig.-1: Oral part of the lipoma.

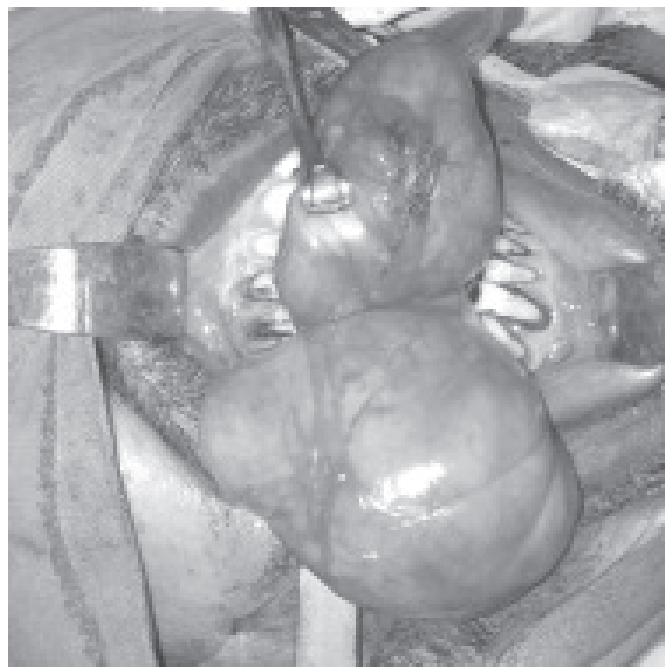

Fig.-2: Both oral and neck part of the lipoma

On both oral and neck palpation it was non tender, soft, fluctuant, compressible and mobile. No neck node was found palpable. Systemic examinations revealed no abnormities. Patient was non diabetic, non hypertensive, non asthmatic and no other comorbidity.

USG revealed a soft tissue mass in the floor of the mouth extended to the right submandibular region. FNAC report was lipoma. Routine tests were normal.

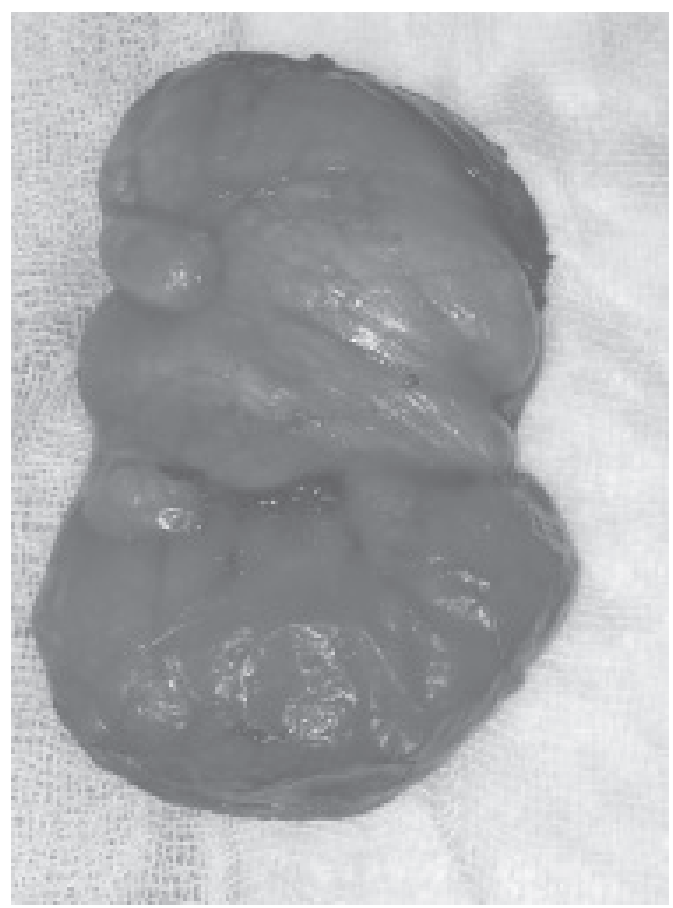

Fig.-3: Excised gross specimen of lipoma.

Excision of the mass was done per-orally under general anaesthesia in National Hospital Pvt. Ltd. in Mehedibag, Chittagong. An incision was given in the right side of the floor of the mouth. The mass was dissected carefully. After that muscles of the floor of the mouth were splitted out and retracted. Then the mass in the neck dissected carefully. Then the whole mass was removed per orally.

Macroscopically the mass was yellowish, soft, well demarcated and bilobbed measuring $9.1 \mathrm{~cm} \times 4 \mathrm{~cm} \times 3 \mathrm{~cm}$. One lobe was above and the other lobe was below the muscles of the floor of the mouth.A pressure bandage was given in the right side of the neck to prevent collection in the neck space. Oral incision was closed keeping a small drain orally which was removed after 24 hours.

Post operatively the functions of the tongue and salivary glands were normal. Histopathological examination of the mass revealed lipoma. 


\section{Discussion}

Lipomas develop mostly in the subcutaneous tissues and only rarely in deep tissues. They most commonly involve the trunk and limbs of the body and seldom the oral and maxillofacial region ${ }^{10,11}$. The female to male ratio for all lipoma is 2 : I but oral lipoma occur more in men than in women $(1.5: 1)^{12}$. Lipoma usually develop in patients over 40 . The buccal mucosa and vestibule are the most commonly involved in intraoral sites. They present as slow growing asymptomatic lesions with yellowish in colour, soft, doughy feel, generally with no gender predilection. Other connective tissue lesions such as granular cell tumor, neurofibroma, traumatic fibroma and salivary gland lesions (mucocele and mixed tumor) might be included in the differential diagnosis ${ }^{13-15}$. The microscopic appearance is circumscribed but not encapsulated aggregate of mature adipocytes with large clear cytoplasm and absence of vascularity is diagnostic of a classical lipoma ${ }^{14}$. Ultrasonography is quick, easy, less costly and with the use of highfrequency transducers it is really suitable for evaluation of superficial structures especially when difficulties exist in identifying the mass from adjacent tissues as it happens in the oral and maxillofacial region. The clinical differential diagnosis includes ranula, dermoid cyst, thyroglossal duct cyst, ectopic thyroid tissue, pleomorphic adenoma, mucoepidermoid carcinoma, angiolipoma, fibrolipoma and malignant lymphoma ${ }^{16-18}$.

\section{Conclusion}

The above case demonstrates the heterogenicity regarding the presentation of the lipoma at a very unusual site, i.e., the floor of the mouth and its remarkable large size. Clinicians and pathologists should keep in mind this unusual presentation of lipoma as a differential diagnosis in a similar case of suspected soft tissue neoplasm to prevent further morbidity of the disease for want of accurate diagnosis. Meticulous clinico pathological evaluation can hit the surprising diagnosis and prevent the untoward complications of treatment modalities.

\section{References}

1. Fregnani ER, Pires FR, Falzoni R, Lopes MA, Vargas PA. Lipomas of the oral cavity: Clinical findings, histological classification and proliferative activity of 46 cases. Int J Oral Maxillofac Surg. 2003;32:49-53

2. Vindenes H. Lipomas of the oral cavity. Int J Oral Surg 1978;7:162-6

3. Ingle SB, Patle YG, Ingle $\mathrm{CH}$, Kediya AS, Gadgil PA. Lipoma in floor of mouth. Indian Med Gaz 2012;8:331-3

4. Bandéca MC, de Pádua JM, Nadalin MR, Ozório JE, Silva-Sousa YT, da Cruz Perez DE. Oral soft tissue lipomas: A case series. J Can Dent Assoc 2007;73:431-4

5. Lawoyin JO, Akande OO, Kolude B, Agbaje JO. Lipoma of the oral cavity: Clinico-pathological review of seven cases from Ibadan. Niger J Med 2001;10:189-91

6. Saitoh $\mathrm{Y}$, Hama $\mathrm{T}$, Ishizaka $\mathrm{S}$, et al. Fibrolipoma of the parotid in a child. Am J Otolaryngol 1995; 16: 433-5

7. Dattilo DJ, Ige JT, Nwana EJ. Intraoral lipoma of the tongue and submandibular space: report of a case. J Oral Maxillofac Surg 1996; 54: 915-7

8. Jablokow VR, Bavafa S. Lipomas of the tongue-report of two cases. J SurgOncol 1982; 21: 114-6

9. Fasig $\mathrm{JH}$, Robinson RA, McCulloch TM, Fletcher MS, Miller CK. Spindle cell lipoma of the parotid: fine-needle aspiration and histologic findings. Arch Pathol Lab Med 2001; 125: 820-1 
10. Dattilo DJ, Ige JT, Nwana EJ. Intraoral lipoma of the tongue andsubmandibular space: report of a case. J Oral Maxillofac Surg 1996; 54: 915-7

11. Epivatianos A, Markopoulos AK, Papanayotou P. Benign tumors of adipose tissue of the oral cavity: a clinico pathologic study of 13 cases. J Oral Maxillofac Surg 2000; 58: 1113-7; discussion 8

12. deVisscher JG. Lipomas and fibrolipomas of the oral cavity. J MaxillofacSurg 1982; 10: 177-81

13. Bandeca M.C., de Padua J.M., Nadalin M.R., Ozorio J.E., Silva-Sousa Y.T., Cruz Perez D.E. - Oral soft tissue lipomas: a case series. J Can Dent Assoc. 73(5):431-434, 2007

14. Adoga A.A., Nimkur T.L., Manasseh A.N., Echejoh G.O. - Buccal soft tissue lipoma in an adult Nigerian:a case report and literature review. $J$ Med Case Reports.2:382, 2008

15. Lawoyin J.O., Akande O.O., Kolude B., Agbaje J.O. —Lipoma of the oral cavity: clinico-pathological review of seven cases from Ibadan. Niger $J$ Med. 10(4):189-191, 2001

16. Del Castillo Pardo de Vera JL, Cebrian Carretero JL, Gomez Garcia E. Chronic lingual ulceration caused by lipoma of the oral cavity. Case report. Med Oral 2004; 9: 166-7, 3-6

17. Capodiferro S, Scully C, Maiorano E, Lo Muzio L, Favia G. Liposarcomacircumscriptum (lipoma-like) of the tongue: report of a case. Oral Dis 2004; 10: $398-400$

18. Piattelli A, Rubini C, Fioroni M, lezzi G. Spindle-cell lipoma of the cheek: a case report. Oral Oncol 2000; 36: 495-6 